УДК $82-312.4,821.581$

DOI 10.25205/1818-7919-2020-19-10-88-99

\title{
Western Literature Translations and Their Impact on the Development of the Detective Genre in China in Early 20 ${ }^{\text {th }}$ Century
}

\section{E. I. Mitkina}

St. Petersburg State University

St. Petersburg, Russian Federation

Abstract

The article is devoted to the study of the impact of Western literature translations on the development of the detective genre in China. Active introduction of China to the Western tradition in the late $19^{\text {th }}-$ early $20^{\text {th }}$ century led to the emergence of a large amount of translated literature. Writers of the first half of the $20^{\text {th }}$ century were innovators, they borrowed in many respects from the form of Western detective stories, which was a rather natural phenomenon considering the necessity to accumulate experience for the creation of a distinct style. A new private detective hero appeared - Huo Sang in Cheng Xiaoqing's novellas, Li Fei in Lu Tan'an's stories, Song Wuqi in Zhang Biwu's stories, as well as the 'anti-detective' gentleman thief Lu Ping in Sun Liaohong's works. Although the names of these writers are not very well known, precisely their works lay the foundation for further development of the detective genre in Chinese literature.

Keywords

Chinese literature of early $20^{\text {th }}$ century, detective literature, detective fiction, Cheng Xiaoqing, Yu Tianfen, Sun Liaohong, Zhang Biwu, Lu Tan'an

For citation

Mitkina E. I. Western Literature Translations and Their Impact on the Development of the Detective Genre in China in Early $20^{\text {th }}$ Century. Vestnik NSU. Series: History and Philology, 2020, vol. 19, no. 10: Oriental Studies, p. 88-99. DOI 10.25205/1818-7919-2020-19-10-88-99

\section{Переводы западной литературы \\ и их влияние на развитие детективного жанра \\ в Китае в начале XX века}

\section{Е. И. Митькина}

Санкт-Петербургский государственный университет

Санкт-Петербург, Россия

\section{Аннотачия}

Данная статья посвящена исследованию влияния переводов западной литературы (Артура Конан Дойля, Мориса Леблана) на развитие детективного жанра в Китае. В конце XIX - начале XX в. началось активное знакомство Китая с Западом, с его миром и литературой. В это время появилось большое количество переводной литературы. Первым переводом на китайский язык западных детективных произведений считается перевод романа «Морской договор» Артура Конан Дойля, опубликованный в 1896 г. в газете «Шиу бао». «Приключения Шерлока Холмса» перевел на китайский язык известный писатель Чэн Сяоцин. Он же создал цикл произведений о китайском детективе Хо Сане - «Приключения Хо Сана», который оказал впоследствии 
значительное влияние на творчество китайских писателей следующих поколений. Еще одним известным писателем, автором детективных произведений в начале ХХ в. был Лу Таньань. В 1924 г. вышли его рассказы в «Сборнике детективных историй о Ли Фэе», главный герой которых - частный детектив. В жанре детектива творил также и известный журналист Чжан Биу. Главным действующим лицом цикла его произведений был детектив Сунь Уци. Еще одним известным писателем первой половины ХХ в., писавшем в жанре детектива, был Сунь Ляохун. Герой его произведений - Лу Пин - во многом (даже именем) напоминает Арсена Люпена. Детективные истории Сунь Ляохуна называют иногда «антидетектив». Под воздействием переводных текстов в китайской литературе появился новый герой - частный детектив, произведения лишаются мистической составляющей, все больше внимания уделяется социальной почве для совершения преступлений. В начале 20-х годов XX в. было более 50 писателей-авторов детективов. Издавались специализированные журналы «Мир детективов» и «Великие детективные произведения», кроме того в ряде газет печатались детективные романы с продолжениями. Все это способствовало развитию детективного жанра в Китае.

Ключевые слова китайская литература начала ХХ века, детективная литература, детективы, Чэн Сяоцин, Юй Тяньфэй, Сунь Ляохун, Чжан Биу, Лу Таньань

Для циттирования

Митькина Е. И. Переводы западной литературы и их влияние на развитие детективного жанра в Китае в начале XX века // Вестник НГУ. Серия: История, филология. 2020. Т. 19, № 10: Востоковедение. С. 88-99. (на англ. яз.) DOI 10.25205/1818-7919-2020-19-10-88-99

The detective genre, in its form familiar to the contemporary reader, emerged in Chinese literature on the verge of the $20^{\text {th }}$ century ${ }^{1}$. However, some of its elements could be encountered much earlier ${ }^{2}$. In his book "Evolution of the Chinese Novel" Vladimir Semanov groups prose works containing detective elements into two genres: the 'chivalric novel' (侠义小说) and the 'crime-case fiction' (公安小说); besides, since these genres often merge, he suggests employing the term 'picaresque (adventure) novel' [Semanov, 1970. P. 62-63]. Judicial case collections, chronicles, historical books, biji (笔记) notes, as well as folk material often served as plot sources. However, the main source was represented by judicial corpora, which appeared during the Song dynasty, such as the "Collection of Complicated Cases", "The Magic Mirror That Solves Cases" or the "Comparison of Cases in the Shade of the Wild Pear" [Van Gulick, 1956. P. 15]. The crime cases therein described were used as storylines, whereas the story itself could change. Leading characters were, as a rule, represented by judges - stories about the judge Bao Zheng (包拯, 9991062), who actually existed, lived in the Song era, and was famed for his honesty and probity, were especially popular. The novel “The Three Heroes and Five Gallants" (三侠五义) by Shi Yukun (石 玉昆), wherein judge Bao is the leading character, especially stands out in this respect. In the late $18^{\text {th }}-19^{\text {th }}$ century, two novels appeared: "Judge Shi's Cases" and "Judge Yu's Cases" whose leading characters were also represented by judges ${ }^{3}$. In the $18^{\text {th }}$ century, the collection "Cases of

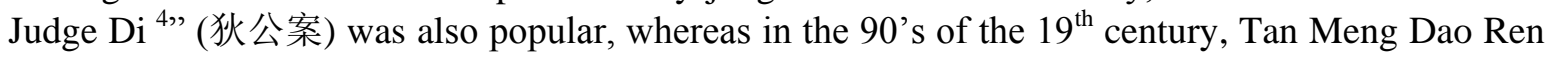
(贪梦道人, Taoist Desirous of Sleep) wrote the “Judge Peng's Cases” (彭公案) telling of the 'just' Qing public official Peng Peng (彭鹏, 1635-1704).

\footnotetext{
${ }^{1}$ Due to the limited volume of the journal article, the author set a specific goal - to introduce new names and showcase new concepts that came into Chinese literature as a result of the influence of Western detective stories. Because of this, tracing the development of crime-case fiction as a whole and detailed development of the influence of early detective stories remained outside the scope of the study. For the same reason, no comparison has been made with other studies of national detective traditions. Moreover, this article does not intend to provide information on the typology of the genre and the comparison of Western research (for example, the works of Tz. Todorov, J. Cawelti, B. Rainov, T. Keszthelyi) and Chinese tradition, since this topic should be reserved for a separate study.

${ }^{2}$ Thus, for example, the judicial theme appears in prose even before the Tang period (there are stories in the Gan Bao collection that tell of judicial practices of the time). Crime-case fiction (公安 Gong'an) was especially widespread in the Qing period (for more details, see [Voskresenskiy, 1966. P. 107-115]).

3 It is supposed that "Judge Shi's Cases" was written no later than 1824, whereas the time when "Judge Yu's Cases" first appeared is unknown [Semanov, 1970. P. 62-63].

${ }^{4}$ In English-language literature, it is customary to write the name of the judge as Judge Dee, this was the name in the collection of stories by Robert van Gulik.
} 
In the late $19^{\text {th }}$ - early $20^{\text {th }}$ century, China began familiarizing actively with the West, with its world, culture, and literature. During that time, a large number of translated works appeared. Moreover, American and European literature had a great impact on the development of its Chinese counterpart. Writers of the first half of the $20^{\text {th }}$ century were innovators of their time. Cheng Xiaoqing, Sun Liaohong, Zhang Biwu in many respects borrowed the form of Western detective fiction - nevertheless, it was quite a natural phenomenon, considering the necessity to accumulate experience for the creation of a distinctly original style. In the fifties, due to attacks from the government, such literature was keenly criticized, detective novels were regarded as samples of bourgeois literature, and during the years of the Cultural Revolution detective fiction almost disappeared. It was the works of the late $19^{\text {th }}$ - early $20^{\text {th }}$ century that formed a base for the subsequent emergence of genuinely Chinese detective fiction directly associated with the history and culture of China.

Translation of "The Adventure of the Naval Treaty" by Arthur Conan Doyle, published in 1896 in the “Shiwu Bao" (时务报) newspaper (see [Cha Jianming, Xie Tianzhen, 2004. P. 35]) made by Zhang Kunde (張坤德), is considered to be the first translation of Western detective fiction into Chinese. In the opinion of Swedish researcher Marja Kaikkonen, the great number of translations that appeared thereafter resulted in the fact that such traditional genre as the crime-case fiction started to fade out; more and more focus was made on Western works [Kaikkonen Marja, 2009].

A spectacular example of the influence and popularity of Western literature is presented in the 1903-1906 novel “The Travels of Lao Can” (老残游记) by Liu E (刘鹗). The work itself does not refer to the detective genre, although it does contain elements of detective fiction. The leading characters Bai Zishou and Lao Can investigate a case of poisoned 'mooncakes' (月饼 yuebing) which caused death to thirteen people. In chapter 18, Bai Jishou says, "Think of it: is it possible to send an ordinary public official to investigate such a case? Absolutely unthinkable! This is why I am asking you, our esteemed Holmes!" [Liu E, 1958. P. 233]. Obviously, Liu E had already been acquainted with Conan Doyle's works, and even more so he wanted to mention them in his own work. This evidences that Liu E read Conan Doyle and was familiar with detective fiction.

Lin Qinnan (林琴南, or Lin Shu 林纾, 1852-1924) was one of the most well-known translators of his time. He did not know foreign languages - usually, an assistant orally translated a text to him, whereupon Lin recorded it in literary wenyan (文言) [Gong Qiongfang, 2013. P. 16-26]. Certainly, mistakes (sometimes double ones - those of the interpreter and the recorder), abridgments, and loose text transmission could arise in the course of such translation, yet Lin Qinnan's translations were important as the first opportunity for Chinese readers to get acquainted with Western literature. The writer Su Xuelin (苏雪林, 1897-1999), who knew foreign languages, noted that "although the translations had certain discrepancies with the original texts, Lin conveyed their spirit with masterly skill" ${ }^{5}$. Moreover, the use of exact wenyan for translation heightened the level of translated works in the eyes of educated readers, which also promoted the popularity of Lin Qinnan's translations, since during that time many writers wrote in vernacular baihua (白话), while texts in wenyan were still considered good style. And though Lin's translations represented translations of non-Chinese, Western literature, their fine literary language made their reading prestigious (though during the period of the May Fourth Movement of 1919, he was criticized specifically for the use of wenyan and overly creative reworking of the original text). He translated over 170 European and American novels and became the first translator of Western literature into Chinese [Cao Zhengwen, 1998. P. 256] ${ }^{6}$. Conan Doyle's stories, which Lin Qinnan translated in 1907-1909, hold a special place among his translations.

\footnotetext{
${ }^{5}$ Su Xuelin. Lin Qinnan xiansheng [苏雪林. 林琴南先生] Mister Lin Qinnan. Ren shi jian, 1934. No. 4. Available at: http://www.bwsk.net/xd/s/shuxuelin/swj/039.htm (accessed 17.07.2020)

${ }^{6}$ He made "The Lady with the Camellias" by A. Dumas, Aesop's fables, "Robinson Crusoe" by D. Defoe, as well as works by Ch. Dickens and Leo Tolstoy available to Chinese readers.
} 
The famous writer Cheng Xiaoqing (程小青, 1893-1976) also translated Conan Doyle (his "Sherlock Holmes" collection). It is notable that he studied forensics, attended forensics and criminology courses held by American universities since 1924. It was also him, who later created a cycle of works about a Chinese detective Huo Sang - “The Adventures of Huo Sang” (霍桑探案), which afterwards made a great impact on the works of Chinese writers of later generations. This cycle resembles in many respects the stories about Sherlock Holmes, wherefrom Cheng Xiaoqing borrowed the 'detective-assistant' concept ${ }^{7}$. They have many similarities: both Sherlock Holmes and Huo Sang are observant people, who may determine a person's nature and habits by the smallest details; besides, both detectives are not married. Even the name of the protagonist of Cheng Xiaoqing's novellas was not chosen randomly - it sounds similar to the English word 'hawk' [Zhu Quanding, 2013. P. 100] for the main hero has a hawkish sight and insight in solving cases.

There are a number of differences: for instance, the leading characters' knowledge structure is not the same. Conan Doyle's Sherlock Holmes has little idea of politics, limited knowledge in botany and geology, but he has an intimate knowledge of anatomy, chemistry, and laws. Huo Sang is adept at various fields - mathematics, physics, chemistry, economics, sociology, philosophy and so on (though he, just like Holmes, pays insufficient attention to literature). Besides, in contrast to Sherlock Holmes, who despises the official police, Huo Sang is friendly towards them, even though he criticizes them at times. There is a certain difference in the choice of investigations as well: Holmes usually takes cases, which would interest him, make his brain work intensively, whereas if he considers a case boring, he won't even take it on. Conversely, Huo Sang takes on the investigation of any crime without classing them into large or small, or deserving attention or not. Conan Doyle's works are characterized by a very vivid description of the surrounding reality, which makes the stories more captivating, evoking the feeling of presence and fear for readers, wherefore the resolutions are absolutely unexpected, whereas Cheng Xiaoqing's works somewhat lack such tense atmosphere ${ }^{8}$.

Cheng Xiaoqing did not aim at creating an image of a superhuman detective - he wrote not only of Huo Sang's insight but also of his mistakes, which rendered more authenticity to his works. His protagonist is just, he always finds a way to help those criminals, who committed crimes based on noble motives. His works have a strict structural composition, a detailed forethought of the design, and a complicated plot. Cheng Xiaoqing used to call detective works "disguised textbooks of popular science" aimed at arousing curiosity with readers and enlightening them [Cheng Haiyan, 2014. P. 20]. He paid great attention to the scientific approach in the investigation of crimes, as well as showed the customs of the old society, where the described crimes take place. Cheng Xiaoqing noted that although the crimes were committed based on different motives, they were always rooted in social problems [Zhou Du, 2014. P. 30]. The emphasis was often made expressly on the social background of the described events. "The distinctive feature of Cheng Xiaoqing's creative style is the fact that he borrows the plots from landmark legal proceedings that took place in the $20^{\text {th }}$ century, but moves the action into his contemporaneity; in the spirit of Western detective fiction, he provides psychological profiles of characters, but, remembering of Chinese readers' taste, does not dismiss realistic descriptions of violent murder scenes" [Zakharova, 2015. P. 58]. In this sense, Cheng Xiaoqing's works conveyed the spirit of their age to a large extent [Song Chuling, 2014. P. 12]. His works had the so-called 'Chinese element' - their action takes place in Shanghai, the author depicted Shanghai lanes longtang (弄堂), residential houses shikumen (石库门), picturesque

\footnotetext{
${ }^{7}$ Both Holmes and Huo Sang have assistants: one has Watson, a retired medical officer, while the other one has Bao Lang, a professional writer. Both assistants, although they participate in investigations, do not play a significant part in the solution of cases. Nevertheless, Cheng Xiaoqing realized the importance of the perspective of specifically the leading character's assistant in plot development. The narration in both cases is first-person - from the leading character's assistant, which renders the feeling of authenticity and engagement with the narration and submerges the reader into the captivating world of the detective story.

${ }^{8}$ Lu Runxiang. Huo Sang yu Fuermosi [卢润祥. 霍桑与福尔莫斯] Huo Sang and Sherlock Holmes. Available at: http://www.millionbook.net/zt/c/chenxiaoqing/000/001.htm (accessed 17.07.2020)
} 
sellers of bean curd tofu (豆腐), etc. Famous journalist Zheng Yimei wrote that Cheng Xiaoqing "devoted his entire life to detective fiction and became a coryphaeus of the detective genre" [Ye Lu, 2004. P. 37]. According to well-known sinologist Natalia Zakharova, "Cheng Xiaoqing's works are yet another proof that translations of the detective fiction, in the same way as all translations of prose, influenced the literature, ideology and social life of China, as well as consolidation of the prose position within the hierarchical system of Chinese literature" [Zakharova, 2015. P. 58].

According to incomplete statistics, the number of detective writers exceeded 50 persons in the early $20^{\text {th }}$ century, whereas the number of works written by them exceeded 200. Apart from a rather famous Cheng Xiaoqing, there also were Lu Tan`an, Yu Tianfen, Sun Liaohong, Zhang Biwu, Hong Xiao, and others. Within the publishing industry and in journalistic circles, in addition to the "World of Detectives" (侦探世界, Zhentan Shije) and “Great Detective Works" (大侦探, Da Zhentan), which attracted readers' attention, a lot of detective novels were printed also in the "Shen Bao" (申报) and the “Xin Wen Bao" (新闻报) newspapers, as well as in sections of other newspapers from issue to issue, which considerably promoted their popularity. All this ensured excellent conditions and opportunities for the detective genre development in China (see [Cao Zhengwen, 1998. P. 74]).

Lu Tan'an (陆澹安, 1894-1980) was yet another famous writer and author of detective works in the early $20^{\text {th }}$ century ${ }^{9}$. Together with Yan Duhe (1889-1968) and Cheng Xiaoqing, he began publishing the magazine "World of Detectives" which was released twice a month. A total of 24 issues had been released between June of 1923 and May of 1924 [Zheng Yimei, 2004. P. 64]; works in the detective genre were published in the magazine. As Fang Ying, the researcher of his works, writes, he held the following views concerning prose works: first, a story must reflect realistic feelings of people; second, 'logic and authenticity' should be observed at image creation; third, a spatiotemporal narrative logic must be present [Fang Ying, 2015. P. 16].

In 1924, a collection of his stories titled "The Collection of Detective Stories about Li Fei” (李飞 探案集) ${ }^{10}$, whose main protagonist was a detective named Li Fei, was released. The collection enjoyed such popularity that it was reprinted several times. Lu Tan'an's works are distinct in the consistency of the unusual plot design.

The leading character, detective Li Fei, was solving complicated cases step by step; readers felt as if they were passing all stages of the investigation together with him, submerging in the tense atmosphere of the stories, which was at times interlaced with mystery and mysticism. In his series of works on Li Fei, Lu Tan'an aspired to adopt for China such a new, one may say, 'exotic' product in detective fiction, often choosing places familiar to him since childhood as the setting. Thereby, the author also showed the morals of his days' society, wherein the greed for gain may put one up to commit terrible crimes - he demonstrated the influence of money on the traditional values and human relations in Shanghai society of that time [Fang Ying, 2015. P. 18].

One of the features of Lu Tan'an's works was his numerous departures from the main theme he used to depict various phenomena in meticulous detail, sometimes adding minor particulars. In all the works, a special role was allotted to detective Li Fei ${ }^{11}$, who combined the best qualities of a talented sleuth: insight, incisiveness, sagacity, ability to pay attention even to such trifles, which seemingly have no direct relation to the matter. Applying the scientific approach in crime investigation, he solved crimes, and that was what brought glory to Li Fei. He nevertheless differs

\footnotetext{
${ }^{9}$ In the very beginning of his career, he worked at a film studio as a scriptwriter for some time, even together with the play writer Hong Shen (1894-1955), and lectured in movie courses. Their students included actors, who later became stars [Fang Ying, 2010. P. 18].

${ }^{10}$ It included five of his stories: "The Needle Wrapped in Cotton" (棉里针), "The Lonely Prisoner of an Old Pagoda" (古塔孤囚), “The Face of the Neighbour” (隔墙人面), “A Scream at Midnight” (夜半呼声), and “A Strange Letter” (怪 函).

${ }^{11}$ From the story "The Needle Wrapped in Cotton", the reader finds out about Liu Fei's life. He was born in Jiangsu Province, and then moved to Shanghai, graduated from Eastern University, whereupon was employed as an officer at a company and at the same time began to work as a detective.
} 
from great and omnipotent sleuths depicted by writers of the West. By temper and actions, Li Fei is closer to traditional Chinese "Confucianist scholars, who were beautiful both in appearance and in their inner qualities" ${ }^{12}$.

Another author, Yu Tianfen (俞天愤, 1881-1937), was on par with Lu Tan`an in the creation of detective stories ${ }^{13}$. In his works the author, as a rule, relates from the first-person point of view, just like in Cheng Xiaoqing's works. With a serious meticulousness, he describes the minutest particulars of the case, finally finding the key to the mystery. Yu Tianfen possessed inventiveness and ingenuity ${ }^{14}$.

In his works, Yu Tianfen reveals dark sides of the life of society; tells about corruption, feuds of militarists ${ }^{15}$, intolerable life of common people; shows ignorance of the police, lack of respect for human life ${ }^{16}$. As a rule, his detective works include a complicated and sophisticated set-up, the reasoning is notable for ingenuity, the plot is elaborate and rich in peripeteia [Wu Peihua, 1991. P. 96], all lines of thought and investigation, in the end, converge to a single final. Although $\mathrm{Yu}$ Tianfen's name is not so famous, his stories influenced the works of both Cheng Xiaoqing and $\mathrm{Lu}$ Tan'an.

Yu Tianfen tried to write stories, which would convey Chinese flavour. It is even said sometimes that his works "are the most remarkable stories in the detective genre since the time of the Xinhai Revolution" [Zhu Mo, 2014. P. 111].

Famous journalist Zhang Biwu (张碧梧, 1897-?) also wrote in the detective genre. He translated works by Maurice Leblanc about a gentleman thief Arsene Lupin into Chinese. Undoubtedly, this influenced his subsequent decision to write detective stories. In 1921, he published his first detective work titled “The Story of Intellectual Duel of Two Heroes" (双雄斗智 记), wherein the Chinese detective Huo Sang (the hero of Cheng Xiaoqing's works) and the Western gentleman criminal Arsene Lupin confront each other in an intellectual struggle. In the foreword, he wrote, "If the West managed to create the images of Sherlock Holmes and Arsene Lupin, why cannot a character as legendary as them appear in the East?" ${ }^{17}$. The work was interesting, although too complicated and not very plausible [Semanov, 1970. P. 90]. The plot itself and the heroes were overly westernized. They wore Western-style suits, smoked cigars, and so on; such western flavour broadened readers' horizons, possessed certain attractiveness, but was far from ordinary life [Tang Zhesheng, 1994. P. 80].

Later, Zhang Biwu created another novel, wherein the leading character was represented by a private detective Song Wuqi - "New Detective Cases of the Private Detective Song Wuqi" (家庭 侦探宋悟奇新探案). The leading character predominantly did not participate in any fights - he won in intellectual struggles with criminals. Besides, Zhang Biwu described various tricks at the investigation of crimes.

\footnotetext{
${ }^{12}$ Ren Xiang. Zhongguo xiandai zhentan xiaoshuojia - Lu Tan’an ji qi zuopin jianjie [任翔. 中国现代侦探小说家陆澹安及其作品简介] Contemporary Detective Writer Lu Tan'an and Review of His Works. 2004a. Available at: http://www.tuili.com/web/Article_Show.asp?ArticleID=66 (accessed 17.07.2020)

${ }^{13}$ His two collections of detective stories published in 1918 - "New Chinese Detective Stories" (中国新探案) and “Conversations on Chinese Detective Fiction” (中国侦探谈), as well as two social novels “A Man in the Mirror” (镜中人, 1916) and “The Stele of Unhappy Lot” (薄命碑, 1916-1917) are most widely known.

${ }^{14}$ An episode is known, when he decided to add illustrations in the form of photos with the view to raise interest for one of his stories, for which he arranged a kind of casting, invited people to image scenes from the story and shot an entire series of photos to print them with the story. This was a novelty - even Western detective works were printed without such sorts of illustrations at that time.

${ }^{15}$ It is known that the writer served at the Red Cross Society in the battle area, helped the wounded and saved dying people [Fan Boqun, 2020. P. 358].

${ }^{16}$ During the Sino-Japanese War, he and his family had to flee his hometown suffering many ordeals and difficulties along the way, which undermined his health, so in $1937 \mathrm{Yu}$ Tianfen died at the age of just 58.

${ }^{17}$ Ren Xiang. Zhongguo xiandai zhentan xiaoshuojia - Lu Tan`an ji qi zuopin jianjie [任翔. 中国现代侦探小说家陆澹安及其作品简介] Contemporary Detective Writer Lu Tan'an and Review of His Works. 2004a. Available at: http://www.tuili.com/web/Article_Show.asp?ArticleID=66 (accessed 17.07.2020)
} 
He wrote an entire cycle about the detective Song Wuqi - twenty-two works, the most remarkable among which are "The Corpse of a Woman in a Suitcase" (箱中女尸) and "The Life after Robbery” (劫后余生). The detective here appears as a high-class professional, and he regularly performs actions, which might be interpreted as deviations from traditional moral norms ${ }^{18}$. As a rule, the action of Zhang Biwu's works took place in Chinese families; the author described crimes that resulted specifically from the confrontation of traditional society and new social trends; he studied various social problems. Zhang Biwu rarely depicted gory details of crimes - he was more interested in unearthing the truth and determining criminals' motives, he taught readers to see the actual state of things underlying any event [Bo Mei, 2004. P. 41].

Zhang Biwu, as was mentioned above, was also a talented journalist - he penned a number of articles devoted to the detective genre. Thus, in 1923 his theoretical articles were printed virtually in every issue of the "World of Detectives".

Yet another famous author of the first half of the $20^{\text {th }}$ century, who wrote in the detective genre, was Sun Liaohong (孙了红, 1897-1958). He was the chief editor of the "Great Detective Works" magazine. His works were on par with those by Cheng Xiaoqing. Moreover, his works are still called one of the highest achievements of the detective genre [Bin Enhai, 2001. P. 10; Liu Jiyu, 2019. P. 22; Peng Dan, 2011. P. 63]. Researcher Yu Min divides his creative work into two periods: 20-30's and 40's. In 1925, Sun Liaohong translated Maurice Leblanc's novels into Chinese, which inspired him to create his works, and therefore he published his first novella "The Puppet Theater" in the "World of Detectives" magazine [Yu Min, 2010. P. 13]. His works of the first period were predominantly imitative, whereas further on, in the 40's, Sun Liaohong's novellas gained distinctness and large popularity ${ }^{19}$.

The hero of his works - Lu Ping - in many respects (even in his name) resembles Arsene Lupin. Professor Jeffrey Kinkley believes that this similarity is superficial, his nobility and courage fascinate, but it should not be taken at face value, such courage also has aforethought of its own. The author himself confirms this trait of his character, admitting that Lu Ping needs valiance only for personal gain [Kinkley, 2000. P. 215]. In contrast to the hero of Cheng Xiaoqing's works, who was a detective, Lu Ping is a thief, who enters rich persons' houses in disguise and employs illegal methods. He detests social injustice, insincerity, and plain falsehood in relations among people, and, moreover, hates the law, which covers up exploits of the rich. This is the cause of his crimes ${ }^{20}$. Sun Liaohong's detective stories are sometimes called 'antidetective' (反侦探) precisely because of the main protagonist. Moreover, this is the only antidetective fiction in China. In early works, Lu Ping operated alone, whereas in later years he finds assistants.

Interestingly, the author rarely shows that his hero has a sense of justice and realization of a higher responsibly and that he carries out investigations from the scientific perspective - that is, he possesses all the traits, which conceivably a detective must have and which heroes of other authors' works possess. Although he robs rich people, he is not a Chinese Robin Hood, for his main purpose is acquiring gain; nevertheless, Lu Ping incidentally commits noble actions every now and again. He is no stranger to romantic feelings, which differs him from, for instance, Arthur Conan

\footnotetext{
${ }^{18}$ For example, in the story "The Corpse of a Woman in a Suitcase" he personally examines the body without any embarrassment or repulse. The story's outcome is also notable when it becomes clear that the murdered woman, modest and brought up in Chinese traditions, suffered by accident, whereas the actual target of the crime - a concubine that ran away from the husband - was saved. In a certain sense, the story showed changes in the minds of people and in the society, reflected the new time characterized by another lifestyle of the society that differed from the traditional one [Kaikkonen, 2009. P. 177-178].

${ }^{19}$ Detective novels such as “The Adventures of the Gentleman Thief Lu Ping” (侠盗鲁平奇案), “Notes on a Night Hunt” (夜猎记), “The Violet Swimming Suit” (紫色游泳衣), “The Blue Rattlesnake”(蓝色响尾蛇), and “The Nonsleeping City" (不夜城) issue from his pen.

${ }^{20}$ Ren Xiang. Zhongguo xiandai zhentan xiaoshuojia - Sun Liaohong ji qi zuopin jianjie [任翔. 中国现代侦探小家孙了红及其作品简介] Contemporary Detective Writer Sun Liaohong and Review of His Works. 2004b. Available at: http://www.tuili.com/web/Article_Show.asp?ArticleID=67 (accessed 17.07.2020)
} 
Doyle's Sherlock Holmes or Cheng Xiaoqing's Huo Sang ${ }^{21}$. This character is alive, of flesh and blood - therefore readers like him so much.

His works excel in suspense, captivating plots, and unexpected outcomes. Sun Liaohong, as a rule, used the change of the narration pace to attract attention - the action took turns to slow down and suddenly become fast-paced and tense. The author kept the suspense up to the end, making readers think together with the main character. In contrast to other detective works, he also likes to show the mindset of his characters, depicting their motives and psychological profiles with scrupulous plausibility. Yet another important feature of his works is love for the description of details, but such descriptions are neither exorbitant nor excessive, they rather serve to set off the events [Liu Jiyu, 2019. P. 22]. As a rule, the writer narrates from the first-person perspective, from the point of view of the thief Lu Ping; however, in some stories the narration is third-person - the writer makes his readers wonder, under the guise of which character the main hero, the gentleman thief Lu Ping, is hiding. Researchers also note a high degree of 'cinematicity' [Peng Dan, 2011. P. 66] of Sun Liaohong's prose replete with dialogues and actions.

Sun Liaohong also demonstrated the evils of his days' society, showing that crimes were closely related to them. Once he said that "[I] wrote stories about a gentleman thief because I felt that the society has degraded morally to such extent that many poor people suffer from the impossibility to strike back. Considering such a serious inequality, I thought it might be interesting if some heroic thief with cunny tricks and ingenious methods appeared - in order to warn certain people in this unfortunate society" [Fan Boqun, 2007. P. 435]. Researcher Zhou Siyu notes that Sun Liaohong "in late years included too much irony and comments as to public morals in his stories" [Zhou Siyu, 2010. P. 16].

Thus, it can be said that the first, early works in the detective genre in China in the first half of the $20^{\text {th }}$ century were greatly influenced by translated literature (especially, works by A. Conan Doyle and M. Leblanc). It was this literature that promoted the emergence of an altogether new character type - a private detective. Second, supernatural forces often helped to identify the criminal in crime-case stories, while in new detective works this fantastic element is already totally absent - heroes find out the truth using their mind, incisiveness, and scientific approach. Third, these works in many respects reflected the life of China at that time and focused on the social background of crimes. And although works (and even names) of these writers are not very well known in the world of detective literature, they nevertheless reflect an entire stage in the development of the very Chinese detective fiction.

\section{References}

Liu E. Puteshestvie Lao Cania [The travels of Lao Can]. Moscow, 1958, 264 p. (in Russ.)

Semanov V. I. Evolyutsiya kitayskogo romana. Konets XVIII - nachalo XX vv. [Evolution of the Chinese Novel. Late $18^{\text {th }}$ - early $20^{\text {th }}$ century]. Moscow, 1970,342 p. (in Russ.)

Voskresenskiy D. N. Sudebnaya povest gunan v Kitaye [The Crime-Case Novella Gong'an in China]. People of Asia and Africa, 1966, no. 1, p. 107-115. (in Russ.)

Zakharova N. V. Perevody Konan Doylya i stanovleniye zhanra detektiva v Kitaye v nachale XX veka [Translations of Conan Doyle and Formation of the Detective Genre in China in Early $20^{\text {th }}$ Century]. Annals of the Nekrasov's Kostroma State University, 2015, vol. 21, p. 55-58. (in Russ.)

Fan Boqun. A History of Modern Chinese Popular Literature. Cambridge University Press, 2020, $752 \mathrm{p}$.

\footnotetext{
${ }^{21}$ If Huo Sang was a protector of law and order, and his actions against criminals are chiefly within the law, Lu Ping is the total opposite; he acts against public order, causing many troubles to the 'dogs of capitalism' - police officers [Jiang Weifeng, 2011. P. 22]. Huo Sang behaves like a gentleman, whereas Lu Ping demonstrates cynicism, he is full of contradicting traits, good and evil cohabitate in him.
} 
Kaikkonen Marja. The Detective in the Service of the Emperor, the Republic, and the Communist Party. In: Literary History: Towards a Global Perspective. Berlin, New York, Walter de Gruvter, 2009, vol. 4, p. 157-198.

Kinkley Jeffrey. Chinese Justice, the fiction: Law and Literature in modern China. Stanford University Press, 2000, 520 p.

Van Gulick Robert Hans. Crime and Punishment in ancient China, T'ang-yin-pi-shih, 1956, 216 p.

Zhou Siyu. The translation of Sherlock Holmes stories and its influence in the Late Qing Dynasty. Shanghai, Shanghai International Studies University, 2010, 41 p.

Bin Enhai. Qian tan Sun Liaohong zhentan xiaoshuo de pingmin yishi [宾恩海。浅谈孙了红侦探 小说的平民意识]. On Mindsets of Common People in Detective Works by Sun Liaohong. Yuedu yи хіеzиo, 2001, no. 6, p. 10-11. (in Chin.)

Bo Mei. “Zi luo lan” zhentan xiaoshuo lun [博玫。《紫罗兰》侦探小说轮]. On the Detective Work "The Violet." Chuangzuo pingtan, 2004, no. 10, p. 40-45. (in Chin.)

Cao Zhengwen. Shijie zhentan xiaoshuo shi lüe [曹正文。世界侦探小说史略]. Brief History of Detective Fiction from Around the World. Shanghai, Shanghai yiwen chubanshe, 1998, 401 p. (in Chin.)

Cha Jianming, Xie Tianzhen. Zhongguo xiandai fanyi wenxue shi [査明建、谢天振。中国现代 翻译文学史 (1898-1949) ]. The History of Contemporary Chinese Translated Literature (1898-1949). Shanghai, Shanghai waiyu jiaoyu chubanshe, 2004, 669 p. (in Chin.)

Cheng Haiyan. Lun Cheng Xiaoqing zhentan xiaoshuo de bentuhua [程海燕。论程小青侦探小说 的本土化]. On Adaptation of Cheng Xiaoqing's Detective Novels. Anqing shifan xueyuan xuebao (shehui kexue ban), 2014, juan 33, no. 5, p. 17-21. (in Chin.)

Fan Boqun. Zhongguo xiandai tongsu wenxue shi [范伯群。中国现代通俗文学史]. The History of Contemporary Chinese Folk Literature. Beijing, Beijing daxue chubanshe, 2007, 596 p. (in Chin.)

Fang Ying. Lu Tan`an biming kao [房莹。陆澹安笔名考]. A Study of Lu Tan`an’s Pseudonyms. Suzhou jiaoyu xиeyuan xuebao, 2010, juan 27, no. 1, p. 15-18. (in Chin.)

Fang Ying. Lu Tan`an de “Qing li zhen shi” xiaoshuo piping guan kao xi [房莹。陆澹安的“情理 真实”小说批评观考析]. An Analysis of the Critical Look on 'Rationality and Authenticity' in Lu Tan'an's Works. Suzhou jiaoyu хиеуиаn хиеbao, 2015, juan 32, no. 6, p. 15-19. (in Chin.)

Gong Qiongfang. Lin yi xiaoshuo zai Qing mo Min chu de chuanbo yanjiu [龚琼芳。林译小说在 清末民初的传播研究]. A Study of Popularity of Novels Translated by Lin Shu in the end of the Qing era - the beginning of the Republic of China. Wuhan, Huadong shifan daxue wenxueyuan, 2013, 142 p. (in Chin.)

Jiang Weifeng. Sun Liaohong zhentan xiaoshuo mianmianguan - jian yu Cheng Xiaoqing xiaoshuo bijiao [姜维枫。孙了红侦探小说面面观一一兼与程小青小说比较]. All Aspects of Sun Liaohong's Detective Works: a Comparison with Cheng Xiaoqing's Works. Jinan daxue xuebao (Shehui kexue ban), 2011, juan 21, no. 5, p. 20-24. (in Chin.)

Liu Jiyu. Lun Sun Liaohong fan zhentan xiaoshuo de xushi yishu [刘吉宇。论孙了红反侦探小说 的叙事艺术]. On the Narrative Art of Antidetective Works by Sun Liaohong. Dangdai xiaoshuo, 2019, no. 3, p. 22-23. (in Chin.)

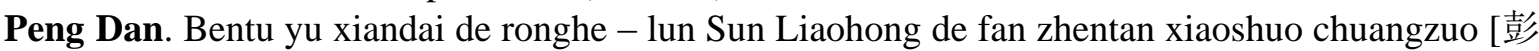
丹。本土与现代的融合——论孙了红的反侦探小说创作]. The Merge of the Local and the Contemporary. On Creation of Antidetective Works by Sun Liaohong. Ankang xиеуиаn xuebao, 2011, juan 23, no. 5, p. 63-66. (in Chin.)

Song Chuling. Zhongguo jin xian dai zhentan xiaoshuo de yingxiang yanjiu - cong «Fuermosi tan an》dao “Huo Sang tan an” [宋楚龄。中国近现代侦探小说的影响研究--从《福尔摩斯探 案》到《霍桑探案》]. The Influence of the New Detective Literature - from “The 
Adventures of Sherlock Holmes" to "The Adventures of Huo Sang." Anhui wenxue, 2014, no. 4, p. 11-12. (in Chin.)

Tang Zhesheng. Zhang Biwu ji qi wenxue chuangzuo [汤哲声。张碧梧及其文学创作]. Zhang Biwu and His Works. Suzhou daxue xuebao (Zhexue shehui kexue ban), 1994, no. 3, p. 78-80. (in Chin.)

Wu Peihua. Tongsu wentan shang de yansu zuojia Yu Tianfen [吴培华。通俗文坛上的严肃作家 俞天愤]. Yu Tianfen, a Serious Writer of Popular Literature. Suzhou daxue xuebao, 1991, no. 4, p. 95-98. (in Chin.)

Ye Lu. Cheng Xiaoqing: Zhongguo “Kenan Daoer” [叶庐。程小青: 中国”柯南道尔”]. Cheng Xiaoqing, the Chinese Conan Doyle. Dongfang jian. Shanghai, Shanghai wenyi chubanshe, 2004, no. 11, p. 37-38. (in Chin.)

Yu Min. Lun Sun Liaohong ji qi fan zhentan xiaoshuo chuangzuo [于敏。论孙了红及其反侦探小 说创作]. Sun Liaohong and His 'Antidetective' Works. Lanzhou, 2010, 41 p. (in Chin.)

Zheng Yimei. Minguo qikan 《Zhentan shijie» [郑逸梅。民国期刊»侦探世界》]. The “World of Detectives" Magazine in the Period of the Republic of China. Wen shi bo lan, 2004, no. 1, 64 p. (in Chin.)

Zhou Du. Cong wenhua shiye kan Cheng Xiaoqing yu Kenan Daoer zhentan xiaoshuo de chayi [周 渡。从文化视野看程小青与柯南道尔侦探小说的差异]. Differences between Cheng Xiaoqing's and Conan Doyle's Detective Prose from the Cultural Perspective. Jiangsu shifan daxue xuebao (Zhexue shehui kexue ban), 2014, juan 40, no. 6, p. 28-32. (in Chin.)

Zhu Mo. Jiafeng zhong de molihua - shi lun Zhongguo xiandai zhentan xiaoshuo de fazhan yu dingxing [朱墨。夹缝中的茉莉花--试论中国现代侦探小说的发展与定型]. A Jasmin in a Crack: On Development and Formation of Contemporary Chinese Detective Works. Shanghai wenxue, 2014, no. 9, p. 107-112. (in Chin.)

Zhu Quanding. 《Fuermosi tan an quanji» dui «Huo Sang tan an ji» de yingxiang [ 朱全定。《福 尔摩斯探案全集》对《霍桑探案集》的影响]. The Influence of “Sherlock Holmes: the Complete Collection" on "The Collection of Adventures of Huo Sang." Shanxi gaodeng xuexiao shehui kexue xuebao, 2013, juan 25, no. 2, p. 99-102. (in Chin.)

\section{Список литературы}

Воскресенский Д. Н. Судебная повесть гунъань в Китае // Народы Азии и Африки. 1966. № 1. С. 107-115.

Захарова Н. В. Переводы Конан Дойля и становление жанра детектива в Китае в начале XX века // Вестник Костром. гос. ун-та им. Н. А. Некрасова. 2015. Т. 21. С. 55-58.

Лю Э. Путешествие Лао Цаня. М.: Гос. изд-во худож. лит., 1958. 264 с.

Семанов В. И. Эволюция китайского романа. Конец XVIII - начало XX в. М.: Наука, 1970. $342 \mathrm{c}$.

Fan Boqun. A History of Modern Chinese Popular Literature. Cambridge University Press, 2020, $752 \mathrm{p}$.

Kaikkonen Marja. The Detective in the Service of the Emperor, the Republic, and the Communist Party. In: Literary History: Towards a Global Perspective. Berlin, New-York, Walter de Gruvter, 2009, vol. 4, p. 157-198.

Kinkley Jeffrey. Chinese Justice, the fiction: Law and Literature in modern China. Stanford University Press, 2000, 520 p.

Van Gulick Robert Hans. Crime and Punishment in ancient China, T'ang-yin-pi-shih, 1956, 216 p.

Zhou Siyu. The translation of Sherlock Holmes stories and its influence in the Late Qing Dynasty. Shanghai, Shanghai International Studies University, 2010, 41 p. 
Бинь Эньхай. Цянь тань Сунь Ляохун чжэньтань сяошо дэ пинминь иши [宾恩海。浅谈孙了 红侦探小说的平民意识]. О сознании простых людей в детективных произведениях Сунь Ляохуна // Юэду юй сецзо [阅读与写作]. 2001. № 6. С. 10-11. (на кит. яз.)

Бо Мэй. «Цзылолань» чжэньтань сяошо лунь [博玫。《紫罗兰》侦探小说轮]. О детективе «Фиалка» // Чуанцзо пинтань [创作评谭]. 2004. № 10. С. 40-45. (на кит. яз.)

Гун Цюнфан. Линь и сяошо цзай Цин мо минь чу дэ чуаньбо яньцзю [龚琼芳。林译小说在 清末民初的传播研究]. Исследование распространения романов, переведенных Линь Шу в конце династии Цин - начале Китайской Республики. Ухань: Хуадун шифань дасюэ вэньсюэюань, 2013. 142 с. (на кит. яз.)

E Лу. Чэн Сяоцин: Чжунго «Кэнань Даоэр» [叶庐。程小青: 中国”柯南道尔”]. Чэн Сяоцин китайский Конан Дойль // Дунфан цзянь [东方剑]. Шанхай: Шанхай вэньи чубаньшэ. 2004. № 11. С. 37-38. (на кит. яз.)

Лю Цзиюй. Лунь Сунь Ляохун фань чжэньтань сяошо дэ сюйши ишу [刘吉宇。论孙了红反 侦探小说的叙事艺术]. О повествовательном искусстве анти-детективных произведений Сунь Ляохуна // Дандай сяошо [当代小说]. 2019. № 3. С. 22-23. (на кит. яз.)

Пэн Дань. Бэньту юй сяньдай дэ жунхэ - лунь Сунь Ляохун дэ фань чжэньтань сяошо чуанцзо [彭丹。本土与现代的融合——论孙了红的反侦探小说创作]. Слияние локального и современного - о создании анти-детективных произведений Сунь Ляохуна // Анькан сюэюань сюэбао [安康学院学报]. 2011 , цзюань 23, № 5. С. 63-66. (на кит. яз.)

Сун Чулин. Чжунго цзинь сянь дай чжэньтань сяошо дэ инсян яньцзю - цун «Фуэрмосы тань ань» дао 《Хо Сан тань ань» [宋楚龄。中国近现代侦探小说的影响研究--从《福尔摩 斯探案》到《霍桑探案》]. Влияние новой детективной литературы - от «Приключений Шерлока Холмса» до «Приключений Хо Сана» // Аньхуэй вэньсюэ [安徽文学]. 2014. № 4. С. 11-12. (на кит. яз.)

Тан Чжэшэн. Чжан Биу цзи ци вэньсюэ чуанцзо [汤哲声。张碧梧及其文学创作]. Чжан Биу и его творчество // Сучжоу дасюэ сюэбао (Чжэсюэ шэхуэй кэсюэ бань) [苏州大学学报 (哲学社会科学版)]. 1994. № 3. С. 78-80. (на кит. яз.)

У Пэйхуа. Тунсу вэньтань шан дэ яньсу цзоцзя Юй Тяньфэнь [吴培华。通俗文坛上的严肃作 家俞天愤]. Юй Тяньфэнь - серьезный писатель популярной литературы // Сучжоу дасюэ сюэбао [苏州大学学报]. 1991. № 4. С. 95-98. (на кит. яз.)

Фан Ин. Лу Таньань бимин као [房莹。陆澹安笔名考]. Исследование псевдонимов Лу Таньаня // Сучжоу цзяоюй сюэюань сюэбао [苏州教育学院学报]. 2010, цзюань 27, № 1. С. 15-18. (на кит. яз.)

Фан Ин. Лу Таньань дэ «Цин ли чжэнь ши» сяошо пипин гуань као си [房荣。陆澹安的“情 理真实”小说批评观考析]. Анализ критического взгляда на «рациональность и подлинность» в творчестве Лу Таньаня // Сучжоу цзяоюй сюэюань сюэбао [苏州教育学 院学报]. 2015, цзюань 32, № 6. С. 15-19. (на кит. яз.)

Фань Боцюнь. Чжунго сяньдай тунсу вэньсюэ ши [范伯群。中国现代通俗文学史]. История современной китайской народной литературы. Пекин: Бейцзин дасюэ чубаньшэ, 2007. 596 с. (на кит. яз.)

Цао Чжэнвэнь. Шицзе чжэньтань сяошо ши люэ [曹正文。世界侦探小说史略]. Краткая история детективных произведений со всего мира. Шанхай: Шанхай ивэнь чубаньшэ. 1998. 401 с. (на кит. яз.)

Цзян Вэйфэн. Сунь Ляохун чжэньтань сяошо мяньмяньгуань - цзянь юй Чэн Сяоцин сяошо бицзяо [姜维枫。孙了红侦探小说面面观一一兼与程小青小说比较]. Все аспекты детективных произведений Сунь Ляохуна - сравнение с творчеством Чэн Сяоцина // 
Цзинань дасюэ сюэбао (шэхуэй кэсюэ бань) [济南大学学报 (社会科学版)]. 2011, цзюань 21, № 5. С. 20-24. (на кит. яз.)

Ча Цзяньмин, Се Тяньчжэнь. Чжунго сяньдай фаньи вэньсюэ ши [査明建、谢天振。中国 现代翻译文学史 ( 1898-1949) ]. История Современной китайской переводной литературы (1898-1949). Шанхай: Шанхай вайюй цзяоюй чубаньшэ, 2004. 669 с. (на кит. яз.)

Чжоу Ду. Цун вэньхуа шие кань Чэн Сяоцин юй Кэнань Даоэр чжэньтань сяошо дэ чаи [周 渡。从文化视野看程小青与柯南道尔侦探小说的差异]. Отличия детективной прозы Чэн Сяо Цина и Конан Дойля с точки зрения культуры // Цзянсу шифань дасюэ сюэбао (Чжэсюэ шэхуэй кэсюэ бань [江苏师范大学学报（哲学社会科学版）]. 2014, цзюань 40, № 6. С. 28-32. (на кит. яз.)

Чжу Мо. Цзяфэн чжун дэ молихуа - ши лунь Чжунго сяньдай чжэньтань сяошо дэ фачжань юй динсин [朱墨。夹缝中的茉莉花--试论中国现代侦探小说的发展与定型]. Жасмин в трещине - о развитии и формировании современных китайских детективных произведений // Шанхай вэньсюэ [上海文学]. 2014. № 9. С. 107-112. (на кит. яз.)

Чжу Цюаньдин. «Фуэрмосы тань ань цюаньцзи» дуй «Хо Сан тань ань цзи» дэ инсян [朱全 定。《福尔摩斯探案全集》对《霍桑探案集》的影响]. Влияние 《Полного собрания произведений о Шерлоке Холмсе» на «Сборник приключений Хо Сана» // Шаньси гаодэн сюэсяо шэхуй кэсюэ сюэбао [山西高等学校社会科学学报]. 2013, цзюань 25, № 2. С. 99-102. (на кит. яз.)

Чжэн Имэй. Миньго цикань 《Чжэньтань шицзе»[郑逸梅。民国期刊》侦探世界»]. Журнал «Мир детективов» в период Китайской республики // Вэнь ши бо лань [文史博览]. 2004. № 1. С. 64. (на кит. яз.)

Чэн Хайянь. Лунь Чэн Сяоцин чжэньтань сяошо дэ бэньтухуа [程海燕。论程小青侦探小说 的本土化]. Об адаптации детективных романов Чэн Сяоцина // Аньцин шифань сюэюань сюэбао (Шэхуэй кэсюэ бань) [安庆师范学院学报(社会科学版)]. 2014, цзюань 33, № 5. С. 17-21. (на кит. яз.)

Юй Минь. Лунь Сунь Ляохун цзи ци фань чжэньтань сяошо чуанцзо [于敏。论孙了红及其 反侦探小说创作]. Сунь Ляохун и его «анти-детективные» произведения. Ланьчжоу, 2010. 41 с. (на кит. яз.)

$$
\begin{array}{r}
\text { Материал поступил в редколлегию } \\
\text { Received } \\
02.08 .2020
\end{array}
$$

\section{Сведения об авторе}

Митькина Евгения Иосифовна, кандидат филологических наук, доцент, кафедра китайской филологии, Санкт-Петербургский государственный университет (Санкт-Петербург, Россия)

e.mitkina@spbu.ru

\section{Information about the Author}

Evgenia I. Mitkina, Candidate of Science (Philology), Associate Professor, Chair of Chinese Philology, St. Petersburg State University (St. Petersburg, Russian Federation) e.mitkina@spbu.ru 